\title{
Corporate Tax Rates and Regional Integration : Evidence from Transition Countries
}

\author{
Aleksandra Klofat \\ University Witten/Herdecke, Witten, Germany
}

\begin{abstract}
Corporate tax rates in the industrialized countries have been decreasing for many years. Many scholars attribute this decline to tax competition. However, less attention has been paid to the relation between regional economic integration and tax rates. This study addresses this issue by concentrating on two integration initiatives in the European Union and the Eurasian Economic Union. This study finds evidence that the declining corporate tax rates are, to the varying extents, driven by the progressive regional integration. The convergence of corporate tax rates also shows that the regional integration within the Eurasian Economic Union is, despite significant skepticism expressed from various angles, working in practice.
\end{abstract}

JEL Classifications: H2, H25, F15

Keywords: Tax Competition, Regional Integration, Eurasian Economic Union, Corporate Tax Rates, Transition Countries

\footnotetext{
* Corresponding Author: Aleksandra Klofat; University Witten/Herdecke, Alfred-Herrhausen-Straße 50, 58448, Witten, Germany, Tel: +49(0)2302/926598, E-Mail: Aleksandra.Klofat@uni-wh.de.

Acknowledgements: I would like to thank the Konrad-Adenauer-Foundation for financial support. I also wish to thank Joachim Zweynert, Gerhard Wegner, Alexander Klemm, Alexander Libman and the participants of the Tax Research Network Conference (University of Hull) and International Conference in Public Economics (Journées Louis-André Gérard-Varet, Institut d'Economie Publique) for their valuable comments.
} 


\section{Introduction}

Corporate tax rates in the industrialized countries have been declining for many years. The Organisation for Economic Co-operation and Development (OECD) average of corporate income tax rates fell from $33.6 \%$ in 2000 to $28.4 \%$ in 2006 . The declining trend in corporate taxation is even more distinct than the rates in 1982, when most OECD countries had rates of approximately 50\% (OECD, 2007). A similar changing pattern in the corporate tax rates is also present in the developing and transition countries of Eastern Europe and Central Asia. Figure 1 shows the development of corporate tax rates in the transition countries.

Figure 1. Corporate tax rate development in transition countries

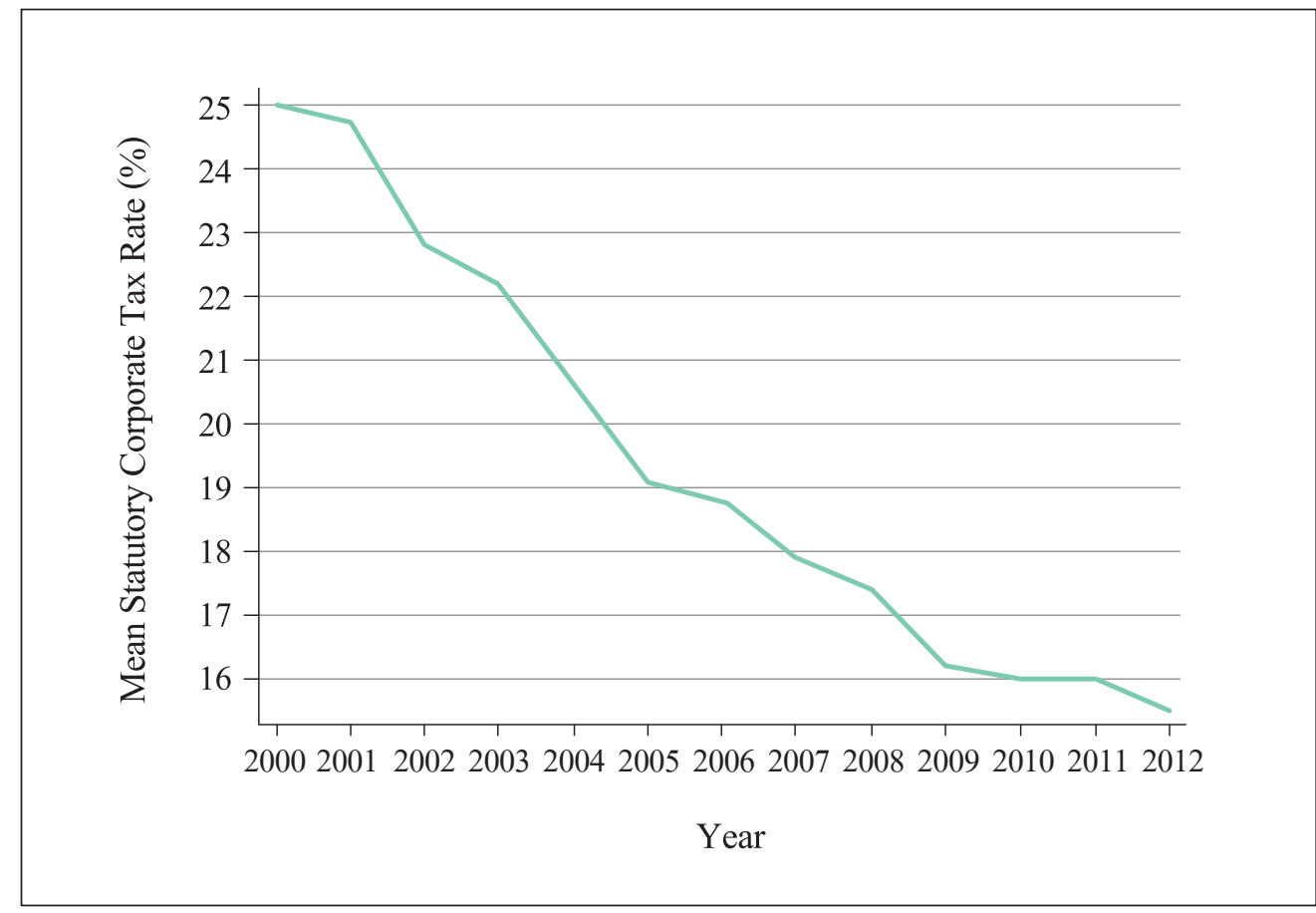

(Note) Statutory corporate tax rate data

(Source) Author's own calculations based on the KPMG data (see Table 1) 
The tendency of falling corporate tax rates, especially in industrialized countries, has been addressed by many scholars. The mechanisms causing the decline in the statutory tax rates and the change in the actual tax burden have been examined frequently, mainly in the area of fiscal studies. These works have provided the impetus for an additional research area that discusses the problem of tax competition between globally interconnected economies and focuses on the question of whether tax competition intensifies with globalization.

The present study contributes to this discussion by identifying the ties between general corporate taxation levels and the degree of regional economic integration. The assumption is that the mechanism responsible for the drop in corporate taxes is the tax competition triggered by the regional integration.

This study empirically focuses on the ongoing integration process in the former transformation countries, both within the European Union (EU) and the Eurasian Economic Community (EurAsEC), which is currently known as the Eurasian Economic Union (EEU). The aim here is to answer the following question: "To what degree the observed changes in corporate taxation can be related to the participation in one of the examined integration initiatives?" In other words, do countries that participate in a regional integration initiative experience more pressure to lower their corporate taxes than the countries that are not integrated in any of those initiatives?

This question is especially interesting with regard to the current integration process within the EurAsEC/EEU. An examination of the corporate tax development within the EurAsEC/EEU also allows partial assessment of the progress of these integration initiatives in practice.

The study is mainly conducted through the application of a regression analysis with controls for state and time fixed-effects. It includes a dataset of transition countries that have been less explored in the context of fiscal studies and, especially, tax competition. Datasets were constructed to extract the benchmarks for corporate taxation within the examined countries, i.e., the statutory corporate tax rate and the total tax rate. The data are collected from the KPMG Corporate and Indirect Tax Survey, various state investment agencies, and the World Bank Development Indicators. Further, a System Generalized Method of Moments (GMM) analysis and a Spatial Autoregressive model (SAR) are applied for validation.

This study suggests that the negative trend in corporate taxation can be accounted for by the progress of regional integration, to a certain extent. These results are notably observable within the Central and Eastern European countries that are part of the EU. 
The results from the countries participating in EurAsEC/EEU integration suggest similar conclusions, confirming the impact of integration on the fiscal policies of its Member States.

In addition, this influence is visible in the improved rankings of Doing Business ${ }^{1}$ in Belarus and Kazakhstan, when compared to Russia, which suggests that smaller countries are trying to improve their position relative to Russia.

These findings are also relevant in light of recent developments of measures against tax avoidance in EU. In 2016, the EU Commission introduced the Anti-Tax Avoidance Package, ${ }^{2}$ which targets various tax-avoidance strategies employed by businesses. During the years of EU integration, some companies developed aggressive tax planning strategies, which took advantage of the EU common market by avoiding corporate taxation in the countries where the profits were actually generated, e.g., by establishing subsidiaries in countries imposing lower corporate taxes or granting tax benefits to selected companies. This led to tax competition between the Member States, which the EU Commission considered to be harmful. ${ }^{3}$ In response, the EU Commission has implemented various legal instruments targeted against such practices.

Strong tax competition within the Eurasian Customs Union and Eurasian Economic Union (CU/EEU) could encourage companies to develop and apply similar aggressive tax planning strategies, as this is already the case within the EU. Subsequently, measures such as the Anti-Tax Avoidance Package could also become necessary within the CU/ EEU. The risk in connection with such strategies is already widely known among Russian politicians, as some of them have expressed their concerns about Russian companies moving to Kazakhstan.

Furthermore, the case of the EurAsEC/EEU is particularly relevant as it comprises countries with autocratic governmental structures, which contrasts with the EU's structure. Other research in the area of regional integration and tax competition mostly concentrates on the EU as an empirical example. It is, however, possible that EU Member States experience more pressure to engage in tax competition because of their democratic structures. Although it may be expected that the autocratic governments of

\footnotetext{
'See World Bank's "Ease of Doing Business Reports".

${ }^{2}$ EU Commission. “Anti-Tax Avoidance Package." (2016).

${ }^{3}$ EU Commission. "Harmful tax competition." (1997).

${ }^{4}$ See, for example, the recent Anti-Tax Avoidance Directive, which issues five measures directed against tax avoidance such as: restricting deductibility of interest, controlling foreign company rules, exit taxation rules, general anti-abuse rules and rules covering hybrid entities. For more detail, see EU Council Directive L193/1 of July 12, 2016.

${ }^{5}$ See Semibratova (2017).
} 
countries like Russia or Kazakhstan have more influence in preventing the occurrence of tax competition, this, in fact, is not the case. This study analytically demonstrates that tax competition as an effect of regional integration is possible, regardless of whether the participating countries are developed democracies.

The rest of the paper is structured as follows. Section II outlines the major findings of the academic literature that tackle the issue of corporate taxation and integration. Section III describes the empirical methodology and reports the results, while Section IV discusses and provides concluding remarks.

\section{Literature Review}

The basic argument within the fiscal studies on tax competition follows the Zodrow and Mieszkowski (1986) tax competition model, which projects a "race to the bottom" regarding the tax rates between local governments and, as a consequence, lower overall levels of the provision of public services. The empirically observed trend in the declining statutory corporate tax rates, at least in the developed countries, seems to confirm this position.

The progressive economic openness and the course of globalization together are often seen as a major trigger for tax competition and the reason for the declining trend in the statutory corporate tax levels. Despite increasing scientific research, however, there is still no predominant opinion about the nexus between tax-setting policies and various measures of economic and political openness. Some studies indicate that increasing globalization does not necessarily influence a country's public policy negatively (see, for example, Garrett 1995 and Swank 2001). In contrast, Rodrik (1997) points to the increasing pressure to lower taxes on capital in step with the increasing openness. Genschel et al. (2011) reach a similar conclusion with regard to the relation between corporate tax rates and the integration within the single EU market. Various outcomes are obtained by Dreher (2006), depending among others upon the specific estimation method of the tax rate on capital.

Less emphasis has been devoted to the more specific forms of economic openness, such as regional integration and its implications on tax competition policies. Mendoza and Tesar (2005) approached the issue of the integration of European financial markets 
and the competition of capital taxes from the perspective of game theory. Their results, however, are mixed, depending on whether countries regulate labor taxes or consumption taxes to maintain fiscal solvency. One empirical study that includes membership in the regional integration initiatives within the OECD countries ${ }^{6}$ as a variable is by Hansson and Olofsdotter (2005). They conclude that integration negatively influences the level of corporate tax rates in the Member States, i.e., it results in decreasing levels of corporate tax rates. Similar results with regard to integration within the EU are achieved by Genschel et al. (2011).

According to Baldwin and Krugman (2004), one reason for the varying research outcomes with regard to tax competition and economic openness may be the fact that the underlying tax competition model does not consider the agglomeration rents that exist in an interconnected economy. According to this argument, the taxation level of a country is not the most important criterion for the investment decision of corporations. Factors like geographical location, infrastructure, and a qualified work force also play an important role in this context. Therefore, countries with strong agglomeration centers are also in a position to raise tax levels without increasing the danger of causing capital outflow. Hence, the agglomeration forces affect the tax competition process and prevent an unconstrained race to the bottom between open economies.

Another possible explanation for the variance in research outcomes regarding tax competition lies in the diversity of the methodological approaches applied by scholars. Major differences concern an adequate measure of economic openness or globalization. The bulk of empirical studies on tax competition employ various measures of trade liberalization and capital mobility as a gauge for economic openness. Slemrod (2004) used two such measures: trade volume (exports and imports of a country in relation to its Gross Domestic Product (GDP)) together with the Sachs and Warner (1995) policy openness index (which has a value 1 if a country is open regarding trade and 0 otherwise). Devereux et al. (2008) used the sum of inward and outward foreign direct investments in relation to GDP as a measure of openness. A further, widely used benchmark for openness is the Quinn (1997) index, which quantifies the degree of financial regulation (varying from 0 to 14 , with 14 indicating the most deregulated country).

Another important methodological issue is the choice of an indicator for the corporate tax burden. Statutory corporate tax rates alone are not a sufficient measure of the actual

${ }^{6}$ EU, European Free Trade Association and other preferential trade arrangements within the OECD. 
corporate tax burden in a country as they do not reflect changes in a country's tax base. Therefore, many other methods of measurement have been developed (see Devereux et al. 2002 for an overview). In general, measurement methods of the corporate tax rate can be divided into two groups: backward-looking and forward-looking measures. Backward-looking measures take the past as the calculation basis and are computed from existing data. One of the most popular methods in this category, developed by Mendoza et al. (1994), considers the ratio between the tax base and tax revenues. In contrast, the forward-looking measures are based on the tax legislation and on the future income of a corporation regarding a hypothetical investment project (see, e.g., Devereux and Griffith 2003).

An additional issue playing an important role in the assessment of fiscal competition is the selection of an appropriate econometric strategy. To capture fiscal competition as a process, many researchers implement a time dimension in their estimations by lagging the dependent variable. Another relatively new way to capture the tax competition effect is to estimate the fiscal reaction function, which basically means regressing a country's tax rate on the weighted average tax rates of other competitive countries. Devereux et al. (2008), for example, applied the fiscal reaction function to estimate the strategic interactions between countries regarding their corporate taxes. Their findings confirm the existence of tax competition with respect to statutory tax rates and also to (weaker) competition regarding effective marginal tax rates (EMTR). Klemm and van Parys (2012) reported similar results for the strategic interaction between developing countries with regard to statutory corporate tax rates and tax holidays. Redoano (2014) applied the fiscal reaction function to examine whether there is a connection between trends in statutory corporate tax rates and EU membership. Davies and Voget (2008) advanced this strategy by examining the effects of EU enlargement on tax competition. In addition, they incorporated the Baldwin and Krugman (2004) argument by designing a weighting scheme, which includes a measure of a country's market potential as a variable. This enables them to make a more precise assessment of each country's economic weight within the EU. Both Redoano's (2014) and Davies and Voget's (2008) findings confirm the existence of tax competition within the EU.

This study complements the existing literature on tax competition in three aspects. First, it conducts a comparative analysis of two integration initiatives: the EU and the EurAsEC/EEU. The EurAsEC/EEU is an integration initiative, which, in major aspects of its institutional framework, leans on the EU concept as a blueprint. Both integration initiatives pursue intense economic and political cooperation, which, in the case of 
EurAsEC/EEU, is additionally reinforced by the common past of the participating countries within the Soviet Union. ${ }^{7}$ Such a combined analysis of two integration initiatives provides new supportive arguments to the already existing studies on tax competition.

Second, this study analyzes a dataset of transition countries, which, until now, has not received any particular attention in this context. Most research regarding tax competition concentrates on the OECD countries, although there is also relatively recent research concerning tax competition in developing countries (see, among others, Keen and Simone 2004, Abbas and Klemm 2013).

Third, the study employs a new, partially self-collected dataset on the statutory corporate tax rate in transition countries and introduces an additional dependent tax variable - the total tax rate - which reflects more of the actual tax burden of businesses. In contrast, Davies and Voget (2008) used the effective average tax rate (EATR) and the statutory tax rate as the dependent tax variables, whereas Redoano (2014) used the statutory tax rate.

The aforementioned issues - accounting for agglomeration forces and selecting a particular indicator for economic openness, together with the choice of a specific research method - are important factors affecting the answers to the particular question regarding tax competition and its relation to regional integration. Section III discusses a strategy for addressing these problems.

\section{Empirical Analysis}

The following analysis focuses on the transition countries in Eastern Europe, including the post-Soviet countries in Central Asia. All these countries share the background of a systemic transformation from a socialist to a market economy. Therefore, they show some similarity in their sociological, economic, and cultural traits. Furthermore, within the transition countries, the analysis clearly distinguishes a particular country's participation in a regional integration initiative. A number of transition countries have become Member States of the EU, and some Eastern European and

\footnotetext{
${ }^{7}$ Common factors include the Russian language as the lingua franca in the region, similar institutional and political developments, and other common historical traits.
} 
Eurasian countries are in the process of integrating within the Eurasian region. Although the post-Soviet countries have initiated many integration initiatives over the past 20 years, ${ }^{8}$ this analysis only includes the integration within the scope of the EurAsEC and the CU/EEU. The reason for this limitation is the fact that until now, these are the only functioning and implemented initiatives. The EurAsEC provided an institutional basis for further integration of its Member States with aims to create a free trade area and customs union among its members. In 2010, these aims were partially realized as the CU came into force, albeit with only a few members of the EurAsEC: Russia, Kazakhstan, and Belarus. Subsequently, the EurAsEC was dissolved at the end of 2014 and consolidated under a new form of the EEU. The EurAsEC and CU organizational structures have been transferred into the EEU framework. ${ }^{9}$

\section{A. Data}

The dataset consists of an unbalanced panel of 29 Eastern European and Eurasian countries, divided into three groups: (1) countries that are members of the EU, (2) countries that are members of EurAsEC and/or CU, ${ }^{10}$ and (3) countries that are not participating in any of the above-mentioned integration initiatives. This distinction allows the differentiation between countries by implementing two different forms of regional integration or none at all.

The observation period spans the 13-year period from 2000 to 2012; hence, it embraces the two extensions of the EU eastwards, ${ }^{11}$ as well as the establishment of the EurAsEC $^{12}$ in 2001 and the $\mathrm{CU}^{13}$ in 2010 (see Appendix 1).

Data on the corporate tax burden for many of the Eurasian and Eastern European countries are not readily available, and of the available datasets, many do not cover the required time span for this study. Furthermore, many of the corporate tax measures, such as the effective tax rate, require additional data for the calculations, which are

\footnotetext{
${ }^{8}$ For a review of integration initiatives in the post-Soviet region, see (among others) Libman and Vinokurov (2012), Valovaya (2012), and Eurasian Economic Commission (2013).

${ }^{9}$ With the exception of the Interparliamentary Assembly, which doesn't exist within the EEU.

${ }^{10}$ All three countries of the CU are also Member States of the EurAsEC.

${ }^{11}$ 2004: Poland, Hungary, Czech Republic, Slovakia, Slovenia, Estonia, Lithuania, Latvia (plus Malta and Cyprus); 2007: Romania and Bulgaria.

${ }^{12}$ Member States: Belarus, Russia, Kazakhstan, Kyrgyzstan, and Tajikistan (Uzbekistan until 2008).

${ }^{13}$ Member States: Belarus, Russia, and Kazakhstan.
} 
either not obtainable or not particularly reliable for many of the countries in Eurasia and Eastern Europe. Because of suspect reliability, calculations based on such data could seriously skew the outcomes. Therefore, this study uses two straightforward measures of the corporate tax burden as dependent variables that are also relatively reliable for the mentioned countries:

- Statutory corporate tax rate;

- Total tax rate.

The statutory corporate tax rate is primarily based on data from the KPMG Corporate and Indirect Tax Survey (2011). The survey collected the data on statutory corporate tax rates from 2000 to 2011. For 2012, the KPMG's Corporate Tax Rates table was used. For the countries where the data in the survey are missing, other data sources were used if available, such as data from national investment agencies or data compiled by Baker $\&$ McKenzie, an international law firm.

One of the problems with using statutory tax data is that these data do not account for the changes in a country's overall tax base. It could be, for example, that a country has a fairly low corporate taxation level; however, because of a broad tax base, the country could still collect the same or greater tax revenues than a country with higher statutory corporate taxation levels. Therefore, this study also introduce a second tax variable - the total tax rate - the information for which is available for most of the examined countries. It measures the tax burden of businesses as a share of commercial profits after all permitted deductions and exemptions and therefore provides a more specific view of the actual tax burden on the companies. The data for the total tax rate were collected from the World Development Indicators (World Bank). The total tax rate is available from 2005 onward.

Figure 2 and Figure 3 provide a graphical exemplification of the general trend in the development of the tax variables in the part of the sample including 12 countries of the former Soviet Union. ${ }^{14}$

${ }^{14}$ Baltic states: Estonia, Lithuania, and Latvia are not included. 
Figure 2. Corporate tax rate developments in the post-Soviet countries

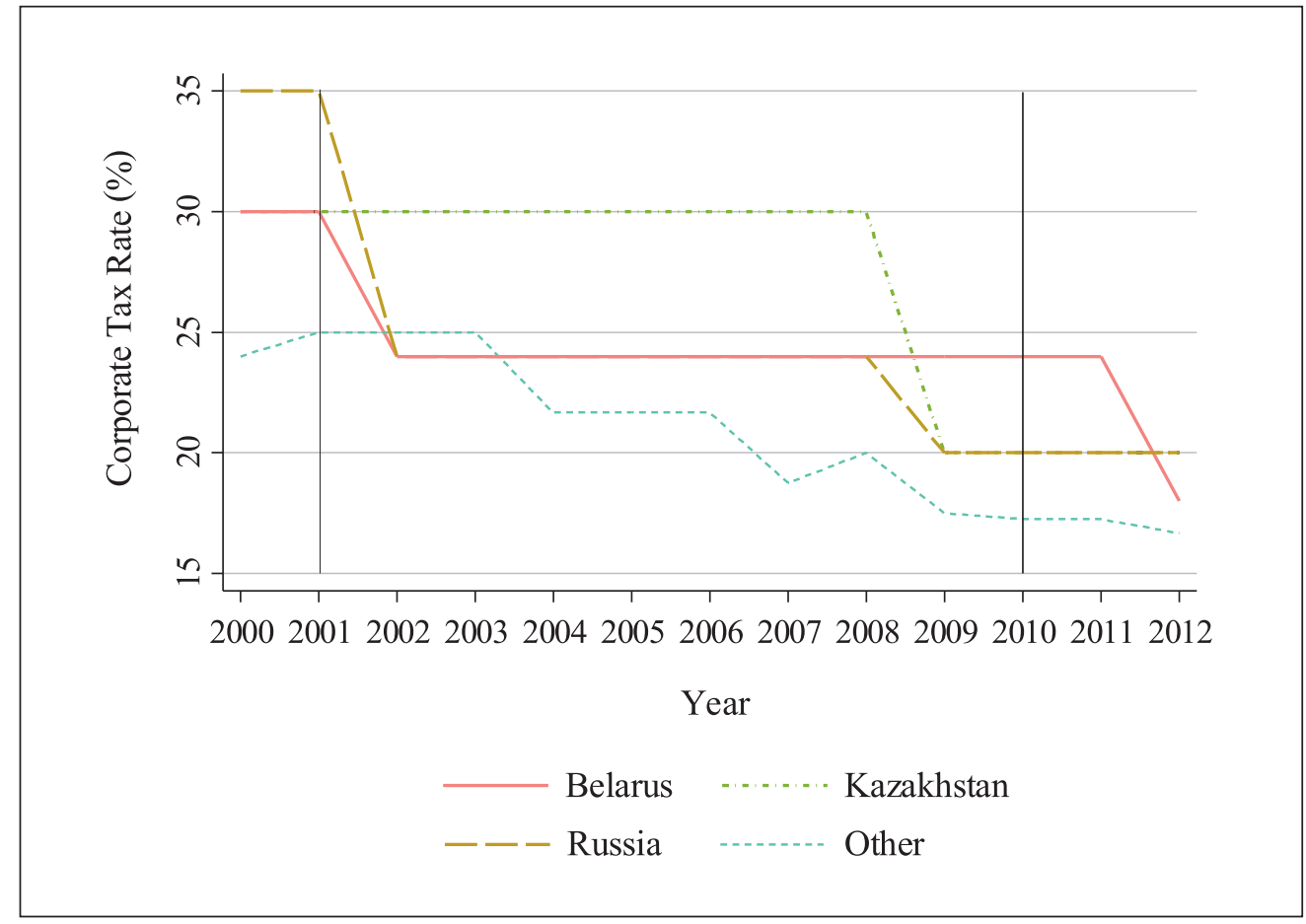

(Note) Figure 2 displays statutory corporate tax rates of the Member States of the CU plus an average corporate tax rate of other post-Soviet countries (without Baltic States), which are marked as "Other" in the legend. Line in 2001 marks the establishment of EurAsEC. Line in 2010 marks the establishment of CU.

(Source) KPMG Corporate and Indirect Tax Survey (see Table 1).

The figures display general declining trends in the tax variables. Figure 2 shows that the declining trend in statutory tax rates is present not only in the EurAsEC countries but also in other countries of the post-Soviet era. However, the figure also displays a stronger decline in the tax rates of Russia and Belarus after 2001, which could suggest an adjustment of the tax rates after the founding of the EurAsEC. ${ }^{15}$ Another sharp drop in the tax rates is apparent around 2010, which also implies that the statutory corporate tax rates have been adjusted because of the establishment of the CU.

\footnotetext{
${ }^{15}$ Around 2001, many of the former Soviet countries introduced major tax reforms. See Stepanyan (2003) for an overview.
} 
Figure 3. Total tax rate development in the post-Soviet countries

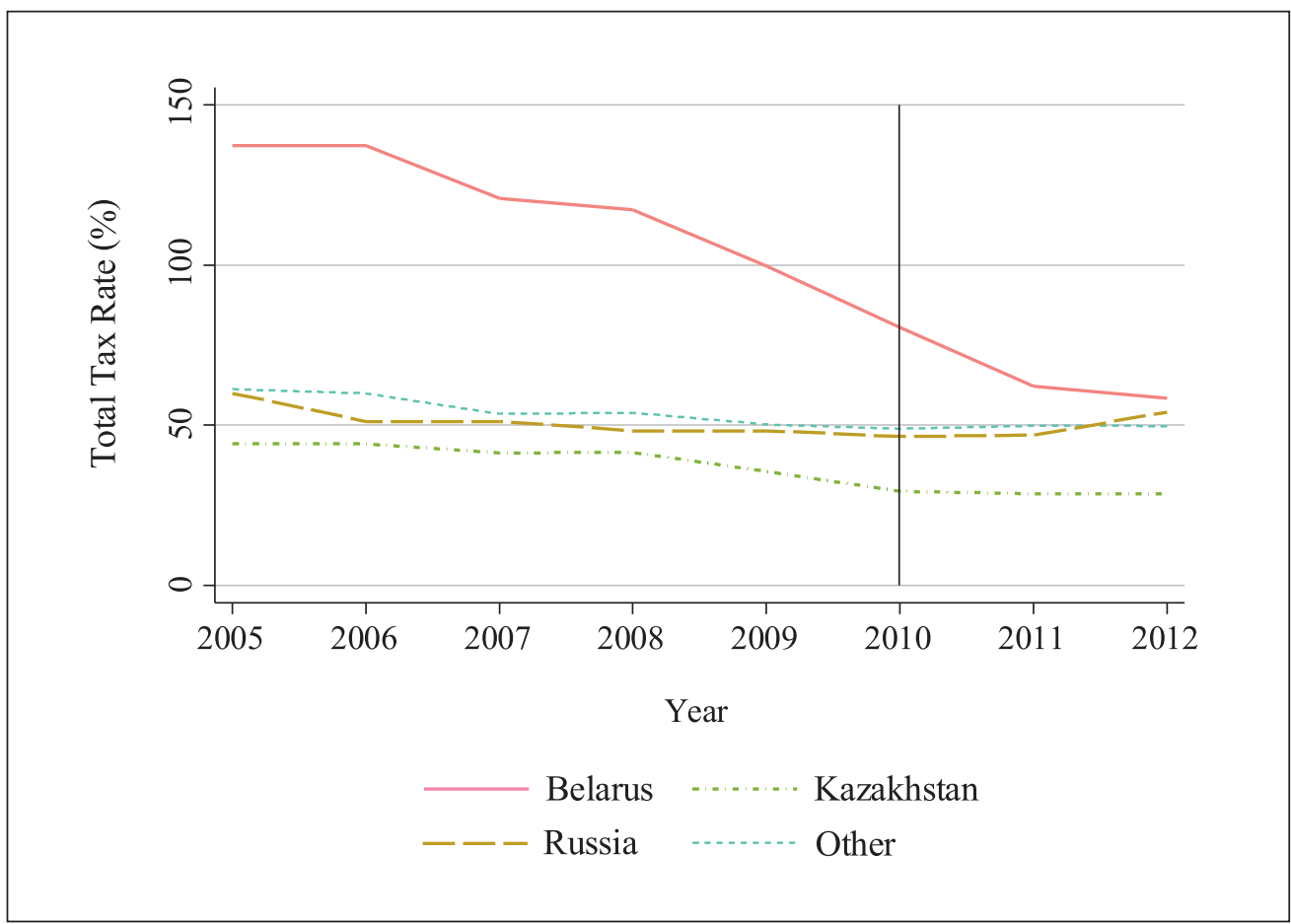

(Note) Figure 3 displays total tax rates of the Member States of the CU plus an average total tax rate of other postSoviet countries (without Baltic States), which are marked as "Other" in the Legend. Line in 2010 marks the establishment of CU.

(Source) World Bank Development Indicators (see Table 1).

Similar adjustments, although not as sharp, are also evident in Figure 3. The graph indicates that Belarus is primarily responsible for the large drop of the total tax rate within the CU, from 137\% in 2005 to 58\% in 2012. Russia's total tax rate remains rather stable, whereas the rate for Kazakhstan drops only slightly. Overall, it appears that the total tax rate of $\mathrm{CU}$ countries converges over time, as the spread among the total tax rate values decreases significantly.

As previously explained, the regional integration variable is a dummy variable that indicates whether a country belongs to the EU, EurAsEC, CU, or none of the integration initiatives.

On the basis of the previous cited theoretical and empirical literature on this topic, the following variables are also included as controls in the estimation: government expenditures, trade, GDP per capita, dependency ratio, and real GDP. 
General government expenditures as a share of GDP are expected to have a positive correlation with corporate tax rates. With rising fiscal needs in a country, the corporate tax rates are also likely to rise (Hansson and Olofsdotter 2005).

The trade variable, which serves as an indicator of a country's openness to international trade, is defined as the sum of the exports and imports of goods and services, divided by GDP. It is assumed that trade should be negatively correlated with the tax variables because of possible pressures to lower taxes with increasing capital mobility.

This study uses GDP per capita as a proxy for the income of the population. It is estimated to be positively correlated with the tax rates because of Wagner's Law, in which rising incomes correspond to an increased demand for public goods (Krogstrup 2006).

The dependency ratio controls for the demographic development of a population. It is defined as the ratio of dependent people (younger than 15 years and older than 64 years) to the working age population. It is assumed that with a rising dependency ratio, corporate taxes in a country will also rise (Dreher 2006).

The GDP in constant US dollars controls for the size of a country's economy and therefore indirectly controls for the agglomeration forces. This is important because of the assumption that a large economy has less pressure to lower its taxation rates in comparison to relatively small economies (Slemrod 2004). 
Table 1. Variables and data source

\begin{tabular}{|c|c|c|}
\hline Variable & Description & Source \\
\hline $\begin{array}{l}\text { Corporate } \\
\text { tax rate }\end{array}$ & Statutory corporate tax rate & $\begin{array}{l}\text { KPMG Corporate and Indirect Tax } \\
\text { Survey 2011; KPMG Corporate } \\
\text { Tax Rate Table; Ministry of Taxes } \\
\text { Republic of Azerbaijan, National } \\
\text { Investment Agency in Georgia } \\
\text { and Uzbekistan (Uzoinvest), } \\
\text { Doing Business Series Baker \& } \\
\text { McKenzie }\end{array}$ \\
\hline $\begin{array}{l}\text { Total } \\
\text { tax rate }\end{array}$ & $\begin{array}{l}\text { "Total tax rate measures the amount } \\
\text { of taxes and mandatory contributions } \\
\text { payable by businesses after accounting } \\
\text { for allowable deductions and exemptions } \\
\text { as a share of commercial profits. Taxes } \\
\text { withheld (such as personal income tax) or } \\
\text { collected and remitted to tax authorities } \\
\text { (such as value added taxes, sales taxes or } \\
\text { goods and service taxes) are excluded." }\end{array}$ & $\begin{array}{l}\text { World Development } \\
\text { Indicators; Doing Business } \\
\text { project (World Bank) }\end{array}$ \\
\hline $\begin{array}{l}\text { Government } \\
\text { expenditure }\end{array}$ & $\begin{array}{l}\text { General government total expenditure as } \\
\text { a percent of GDP }\end{array}$ & $\begin{array}{l}\text { IMF, World Economic Outlook } \\
\text { Database }\end{array}$ \\
\hline Trade & $\begin{array}{l}\text { "The sum of exports and imports of goods } \\
\text { and services measured as a share of gross } \\
\text { domestic product" }\end{array}$ & $\begin{array}{l}\text { World Development Indicators } \\
\text { (World Bank) }\end{array}$ \\
\hline $\begin{array}{l}\text { GDP per } \\
\text { capita }\end{array}$ & $\begin{array}{l}\text { Gross domestic product divided by } \\
\text { midyear population. In constant } 2005 \text { US } \\
\text { dollars }\end{array}$ & $\begin{array}{l}\text { World Development Indicators } \\
\text { (World Bank) }\end{array}$ \\
\hline $\begin{array}{l}\text { Dependency } \\
\text { ratio }\end{array}$ & $\begin{array}{l}\text { "Age dependency ratio is the ratio of } \\
\text { dependents-people younger than } 15 \\
\text { or older than } 64 \text {-to the working-age } \\
\text { population-those ages } 15 \sim 64 \text {. Data are } \\
\text { shown as the proportion of dependents per } \\
100 \text { working-age population." }\end{array}$ & $\begin{array}{l}\text { World Bank } \\
\text { (World Development } \\
\text { Indicators) }\end{array}$ \\
\hline$G D P$ & $\begin{array}{l}\text { Real Gross Domestic Product in constant } \\
2005 \text { US dollars (divided by Million) } \\
\text { GDP/1000000 }\end{array}$ & $\begin{array}{l}\text { World Bank } \\
\text { (World Development } \\
\text { Indicators) }\end{array}$ \\
\hline
\end{tabular}




\section{B. Basic estimation: fixed-effects}

\section{Estimation}

To answer the research question, i.e., whether and to what extent there is a nexus between regional integration and corporate tax levels, the following fixed-effects regression model is estimated:

$$
\text { Corporate Taxation }_{i t}=\alpha_{0}+\beta_{1} \text { Integration }_{i t}+\beta_{2} X_{i t}+\mu_{i}+\tau_{t}+v_{i t}
$$

Corporate Taxation represents the two above-identified tax measures: the statutory corporate tax rate and the total tax rate.

Integration is a dummy variable indicating whether a country belongs to one of the mentioned integration initiatives.

$X$ represents the set of control variables, $\mu_{i}$ is the country fixed-effects, $\tau_{t}$ is the period fixed-effects, and $v_{i t}$ is the error term.

In the basic specification, this study examines the relation between all the abovementioned integration initiatives taken together and each of the two corporate tax rate variables.

With regard to the total tax rate, because of the fact that the data are only available for 2005 onward, the estimations do not include all of the integration memberships. Specifically, they do not include the EurAsEC integration since this initiative came into effect in 2001; also, they do not consider the 2004 eastward expansion of the EU.

In subsequent specifications, the estimation for each of the integration initiatives and tax variables are separately calculated.

\section{Results}

Table 2 presents the results of the two-way fixed-effects regressions, with the corporate tax rate and total tax rate as dependent variables. The results of the basic specifications are presented in row (1) for the corporate tax rate and row (5) for the total tax rate. 
Table 2. Impact of integration on corporate taxation levels

\begin{tabular}{|c|c|c|c|c|c|c|c|}
\hline \multirow{3}{*}{ Model } & \multicolumn{7}{|c|}{ Fixed-Effects Estimation } \\
\hline & \multicolumn{4}{|c|}{ Corporate Tax Rate } & \multicolumn{3}{|c|}{ Total Tax Rate (since 2005) } \\
\hline & (1) & (2) & (3) & (4) & (5) & (6) & (7) \\
\hline Integration & $\begin{array}{c}-3.025^{* *} \\
(1.122)\end{array}$ & & & & & & \\
\hline $\begin{array}{l}\text { Integration } \\
\text { (no EurAsEc) }\end{array}$ & & & & & $\begin{array}{c}-14.492 * \\
(7.684)\end{array}$ & & \\
\hline$E U$ & & $\begin{array}{c}-2.544 * \\
(1.277) \\
\end{array}$ & & & & $\begin{array}{l}-2.577 \\
(3.206)\end{array}$ & \\
\hline$C U$ & & & $\begin{array}{l}-2.013 \\
(2.113)\end{array}$ & & & & $\begin{array}{c}-20.824^{*} \\
(11.577)\end{array}$ \\
\hline EurAsEC & & & & $\begin{array}{c}-3.487^{* *} \\
(1.480)\end{array}$ & & & \\
\hline $\begin{array}{l}\text { Government } \\
\text { expenditure }\end{array}$ & $\begin{array}{c}0.057 \\
(0.069)\end{array}$ & $\begin{array}{c}0.023 \\
(0.074)\end{array}$ & $\begin{array}{c}0.005 \\
(0.073)\end{array}$ & $\begin{array}{c}0.049 \\
(0.080)\end{array}$ & $\begin{array}{c}0.571 \\
(0.631)\end{array}$ & $\begin{array}{c}0.800 \\
(0.845)\end{array}$ & $\begin{array}{c}0.485 \\
(0.556)\end{array}$ \\
\hline Trade & $\begin{array}{l}-0.01 \\
(0.028)\end{array}$ & $\begin{array}{l}-0.014 \\
(0.029)\end{array}$ & $\begin{array}{c}-0.028 \\
(0.26)\end{array}$ & $\begin{array}{l}-0.021 \\
(0.031)\end{array}$ & $\begin{array}{l}-0.078 \\
(0.113)\end{array}$ & $\begin{array}{l}-0.060 \\
(0.116)\end{array}$ & $\begin{array}{l}-0.082 \\
(0.110)\end{array}$ \\
\hline GDP/Capita & $\begin{array}{c}0.0004 \\
(0.0006)\end{array}$ & $\begin{array}{c}0.0003 \\
(0.0006)\end{array}$ & $\begin{array}{l}-0.0003 \\
(0.0005)\end{array}$ & $\begin{array}{l}-0.0003 \\
(0.0005)\end{array}$ & $\begin{array}{c}-0.0007 \\
(0.002)\end{array}$ & $\begin{array}{l}-0.001 \\
(0.002)\end{array}$ & $\begin{array}{c}-0.0008 \\
(0.002)\end{array}$ \\
\hline $\begin{array}{l}\text { Dependency } \\
\text { ratio }\end{array}$ & $\begin{array}{c}0.445 \\
(0.300)\end{array}$ & $\begin{array}{c}0.415 \\
(0.301)\end{array}$ & $\begin{array}{c}0.313 \\
(0.314)\end{array}$ & $\begin{array}{c}0.335 \\
(0.304)\end{array}$ & $\begin{array}{c}0.628 \\
(0.702)\end{array}$ & $\begin{array}{c}0.329 \\
(0.678)\end{array}$ & $\begin{array}{c}0.439 \\
(0.650)\end{array}$ \\
\hline$G D P$ & $\begin{array}{c}-0.012 * * * \\
(0.004)\end{array}$ & $\begin{array}{c}-0.014 * * * \\
(0.004)\end{array}$ & $\begin{array}{l}-0.008 \\
(0.006)\end{array}$ & $\begin{array}{l}-0.008 \\
(0.005)\end{array}$ & $\begin{array}{l}0.066^{*} \\
(0.037)\end{array}$ & $\begin{array}{c}0.015 \\
(0.030)\end{array}$ & $\begin{array}{l}0.097^{*} \\
(0.052)\end{array}$ \\
\hline $\begin{array}{l}\text { Number of } \\
\text { countries }\end{array}$ & $25 / 29$ & $25 / 29$ & $25 / 29$ & $25 / 29$ & $28 / 29$ & $28 / 29$ & $28 / 29$ \\
\hline $\begin{array}{l}\text { Number of } \\
\text { observations }\end{array}$ & 263 & 263 & 263 & 263 & 210 & 210 & 210 \\
\hline$R^{2}$ (within) & 0.62 & 0.61 & 0.60 & 0.60 & 0.41 & 0.31 & 0.44 \\
\hline
\end{tabular}

(Note) (i) The columns display the results of fixed-effects regressions for both: corporate tax rate (1 to 4$)$ and total tax rate (5 to 7 ) as dependent variables.

(ii) Regressions (1) and (5) are basic estimations and show the impact of each tax rate for all integration initiatives taken together. Regressions (2) and (6) show the results for the EU only and regressions (3) and (7) display the results for the CU only. Additionally regression (4) displays the results for the EurAsEC. Regression (5) does not include EurAsEC due to lack of data for this period of time.

(iii) Robust standard errors are reported in parentheses. Stars indicate levels of significance: ***: 1 percent, **: 5 percent, *: 10 percent. 
In the first specification (1), with the statutory corporate tax rate as the dependent variable, there is a negative and significant correlation between the corporate tax rate and the examined integration initiatives, which confirms the assumption that regional integration contributes to the negative trend of corporate taxation, at least at the statutory level. In the basic specification (5), with the total tax rate as a dependent variable, the correlation is also negative and statistically significant. Both basic estimations suggest that corporate taxation tends to fall with an increased level of regional integration.

Similar results are also obtained when each of the integration initiatives is accounted for individually. Each of the integration areas is negatively correlated both with the corporate and total tax rate with varying significance levels, except that for $\mathrm{CU}$, which is negative but not significant with respect to the statutory corporate tax rate, and that for the EU, which is also negative but insignificant in specification (6). The most likely reason for no significance in the case of the EU is that the total tax rate specification does not include the large $2004 \mathrm{EU}$ enlargement. In the case of CU, the result becomes significant if the observation span is shortened. In the original observation period of 13 years, CU began relatively late in 2010; therefore, its impact amounts to only two years of observations. In contrast, when the observation period begins in 2004, the impact of $\mathrm{CU}$ is greater and the results become significant.

Notable is the fact that the CU coefficient in the estimation with the total tax rate as the dependent variable is much larger than that with the statutory corporate tax rate. This de facto means that the founding of the CU paralleled the strong declining trend in the tax burden for companies in the Member States. The large coefficient of CU in the estimation (7) transfers to the overall estimation (5) and increases the coefficient there as well. Figure 3 shows that the large decline in the total tax rates within CU can be primarily attributed to Belarus. This trend with regard to Belarus is also apparent in the overall "Ease of Doing Business" rankings by the World Bank, wherein Belarus moves up from 124th place in 2006 to 58th in 2013. A similar pattern is also observable for Kazakhstan, which moves up from 82nd place in 2006 to 49th in 2013. Russia, however, stayed in a fairly the same position over this period, oscillating between rank 97 and 112. This pattern complies with the total tax rate development projected in Figure 3 for the total tax rate. This development suggests that Russia is the prime driver behind the drop in total tax rates levels within $\mathrm{CU}$, as other countries adjust their tax levels with Russia after joining the CU.

Another partially significant variable in the estimations is real GDP, indicating the size of an economy. It is negative in the specifications with the statutory corporate tax 
rate as the dependent variable, which, in this case, means (contrary to the agglomeration thesis) that the countries with larger GDPs tend to have lower statutory tax rates on corporate income. However, the outcome is opposite to the case of the total tax rate (specifications 5 7), wherein the connection between these two variables is positive (significant at the 10\% level). Therefore, it seems that the countries with higher GDPs tend to have higher actual tax rates. This result seems plausible, especially for CU, where Russia, as a very large economy, can afford to have higher tax rates.

The variable trade, which acts as a proxy for a country's general openness to the global economy, also has no significant correlation in either specification. However, the trade variable remains negative in all specifications, suggesting a similar relation as that in the specifications with the regional integration variables, i.e., increasing trade openness goes together with decreasing corporate tax levels.

Demographic factors represented by the age dependency ratio proxy appear to have a positive but not significant connection with corporate taxation levels. This corresponds with the expected direction of the correlation by anticipating that a growing number of dependents in a country's population contribute toward rising corporate tax rates.

The overall results indicate a relatively strong relation between corporate taxation levels and integration processes in the Eastern European and post-Soviet countries. The results provided by the estimations confirm that the regional integration processes developing in Eastern Europe and Eurasia have a significant negative effect on the statutory corporate tax rates.

The correlation between corporate taxation and other factors principally supports the assumptions made in the beginning of this section. The exceptions are the relation between GDP and the statutory corporate tax rate and the relation between GDP per capita in the specifications with $\mathrm{CU}$ and in the specifications for the total tax rate.

The next section of this analysis further specifies the estimations to clarify whether this relation holds if other factors that may influence the outcomes are considered.

\section{System GMM}

\section{Estimation}

To verify the results from the fixed-effects estimation, a second approach is to introduce the time dimension in the calculations of this analysis. This methodology 
allows addressing the problem of autocorrelation of the dependent variable over time. It is plausible to assume that, for example, the current corporate tax rate levels are dependent upon their own values in the previous year. Lagging the dependent variable allows the introduction of a time dimension to the equation and, to some degree, accounts for the gradual adjustment of tax rates in the observed countries.

Fixed-effect estimations produce biased results when lagging the dependent variable (Nickell 1981). Therefore, the GMM estimations are used, as generally specified by Arellano and Bond (1991) and augmented by Arellano and Bover (1995), and Blundell and Bond (1998).

The basic GMM equation is as follows:

$$
\text { Corporate Taxation }_{i t}=\beta_{1} \text { Corporate Taxation }_{i, t-1}+\beta_{2} \text { Integration }_{i t}+\beta_{3} X_{i t}+\varepsilon_{i t}
$$

Corporate Taxation on the right side of the equation represents the lagged dependent variable. Similar to the fixed-effects equation, the Integration variable indicates whether a country belongs to one of the integration initiatives, $X_{i t}$ represents the set of control variables, and $\varepsilon_{i t}$ is the error term.

The system GMM estimator is used in accordance with Arellano and Bover (1995) and Blundell and Bond (1998). The estimation method applies GMM, as specified by Hansen (1982).

The suggested system GMM method has many advantages but also many requirements that must be fulfilled to achieve reliable results. In general, it has been designed for relatively short panel datasets (a short number of time periods and a large number of individuals). The most important caveat toward applying the GMM method is, however, the danger of instrument proliferation, which renders the outcomes of the estimations as unreliable. ${ }^{16}$ Clearly, the present study's dataset of countries does not exactly fulfill these requirements. These issues are addressed in the analysis by estimating, among other methods, a system GMM instead of a difference GMM. As Soto (2009) pointed out, the system GMM estimator delivers better results than the difference GMM estimator in small samples. Furthermore, the number of lags is adjusted and the Hansen test is employed for this study's estimations.

Another problem arises through lagging of the dependent variable with EurAsEC integration in the corporate tax rate estimation. Because of the relatively early start

\footnotetext{
${ }^{16}$ For an overview of requirements and possible caveats, see Roodman (2009).
} 
of EurAsEC integration in 2001, it cannot be included in the GMM estimation with the statutory corporate tax rate. Similarly, regarding the fixed-effects estimations, the EurAsEC integration and the 2004 EU enlargement with the total tax rate cannot be included because of data unavailability.

\section{Results}

The above-mentioned constraints make the results of the GMM estimations much less reliable than those of the fixed-effects estimations. The relatively high $p$-values of the Hansen test point toward the danger of instrument proliferation. Rather, it is advisable to consider the GMM estimations as an addition to the fixed-effects model, which is more consistent in this situation.

The most noticeable observation is that the lagged corporate tax variables are significant in all of the specifications. The significant presence of autocorrelation in the tax variables confirms the assumption that both tax variables are dependent upon their previous values. Also noteworthy is that in the case of the GMM estimations, the number of observations is lower than in the case of the fixed-effects estimations. The cause of this observation loss is the implementation of the lagged dependent variable.

The overall results also show, similar to the fixed-effects estimations, a largely negative relation between the integration variables and corporate tax variables. The significant outcomes in the specifications (2) with the EU and (6) with the CU are both similar to those of the fixed-effects estimation. The outcomes can be partially explained by the dynamic structure of the estimation, i.e., lagging of the dependent variable, which reduces the number of observations, particularly with respect to CU. With regard to the $\mathrm{EU}$, the positive relation in specification (5) could originate from the fact that the dataset excludes the major part of the eastward expansion. The cause for the mixed outcomes with regard to the GMM estimations with $\mathrm{CU}$ can also be seen in Figures 2 and 3. While the total tax rates, especially for Belarus, have been drastically adjusted around the time of CU inception, the statutory corporate tax rates had their sharpest decline after the founding of EurAsEC between 2001 and 2003. This decline, similar to the EU enlargement in 2004, could not be captured by the GMM estimation. 
Table 3. Impact of integration on corporate taxation

\begin{tabular}{|c|c|c|c|c|c|c|}
\hline \multirow{3}{*}{ Model } & \multicolumn{6}{|c|}{ System GMM Estimation } \\
\hline & \multicolumn{3}{|c|}{ Corporate Tax Rate } & \multicolumn{3}{|c|}{ Total Tax Rate (since 2005) } \\
\hline & (1) & (2) & (3) & (4) & (5) & (6) \\
\hline $\begin{array}{l}\text { Integration } \\
\text { (no EurAsEC) }\end{array}$ & $\begin{array}{l}-1.420 \\
(1.047)\end{array}$ & & & $\begin{array}{l}-12.962 \\
(11.980)\end{array}$ & & \\
\hline$E U$ & & $\begin{array}{c}-3.200 * * \\
(1.307)\end{array}$ & & & $\begin{array}{c}5.041 \\
(19.947)\end{array}$ & \\
\hline$C U$ & & & $\begin{array}{l}2.644 \\
(2.429)\end{array}$ & & & $\begin{array}{c}-13.000^{*} \\
(7.112)\end{array}$ \\
\hline $\begin{array}{l}\text { Government } \\
\text { expenditure }\end{array}$ & $\begin{array}{l}-0.053 \\
(0.078)\end{array}$ & $\begin{array}{l}-0.038 \\
(0.081)\end{array}$ & $\begin{array}{l}-0.054 \\
(0.075)\end{array}$ & $\begin{array}{l}-0.148 \\
(0.964)\end{array}$ & $\begin{array}{l}-0.444 \\
(0.302)\end{array}$ & $\begin{array}{c}0.008 \\
(0.711)\end{array}$ \\
\hline Trade & $\begin{array}{c}0.005 \\
(0.017)\end{array}$ & $\begin{array}{c}0.011 \\
(0.025)\end{array}$ & $\begin{array}{l}-0.006 \\
(0.021)\end{array}$ & $\begin{array}{c}0.160 \\
(0.355)\end{array}$ & $\begin{array}{c}0.015 \\
(0.114)\end{array}$ & $\begin{array}{c}0.226 \\
(0.238)\end{array}$ \\
\hline GDP/Capita & $\begin{array}{c}0.0003 \\
(0.0002)\end{array}$ & $\begin{array}{c}0.0005 * * \\
(0.0002)\end{array}$ & $\begin{array}{c}0.0003 \\
(0.0002)\end{array}$ & $\begin{array}{l}-0.003 \\
(0.009)\end{array}$ & $\begin{array}{c}-0.0007 \\
(0.003)\end{array}$ & $\begin{array}{l}-0.004 \\
(0.008)\end{array}$ \\
\hline $\begin{array}{l}\text { Dependency } \\
\text { ratio }\end{array}$ & $\begin{array}{c}0.041 \\
(0.069)\end{array}$ & $\begin{array}{l}-0.008 \\
(0.084)\end{array}$ & $\begin{array}{c}0.016 \\
(0.082)\end{array}$ & $\begin{array}{c}0.186 \\
(1.234)\end{array}$ & $\begin{array}{c}0.468 \\
(0.464)\end{array}$ & $\begin{array}{l}-0.065 \\
(0.971)\end{array}$ \\
\hline$G D P$ & $\begin{array}{c}0.003 \\
(0.002)\end{array}$ & $\begin{array}{l}0.0008 \\
(0.003)\end{array}$ & $\begin{array}{c}-0.0007 \\
(0.005)\end{array}$ & $\begin{array}{c}0.083 \\
(0.162)\end{array}$ & $\begin{array}{c}0.037 \\
(0.080)\end{array}$ & $\begin{array}{c}0.086 \\
(0.130)\end{array}$ \\
\hline $\begin{array}{l}\text { Lagged dependent } \\
\text { variable }\end{array}$ & $\begin{array}{c}0.860 * * * \\
(0.070)\end{array}$ & $\begin{array}{c}0.875^{* * *} \\
(0.065) \\
\end{array}$ & $\begin{array}{c}0.975^{* * *} \\
(0.082)\end{array}$ & $\begin{array}{c}0.701 * * \\
(0.256) \\
\end{array}$ & $\begin{array}{c}0.790 * * * \\
(0.159) \\
\end{array}$ & $\begin{array}{c}0.736^{* * *} \\
(0.265) \\
\end{array}$ \\
\hline $\begin{array}{l}\text { Number of } \\
\text { countries }\end{array}$ & 24 & 24 & 24 & 28 & 28 & 28 \\
\hline $\begin{array}{l}\text { Number of } \\
\text { observations }\end{array}$ & 240 & 240 & 240 & 183 & 183 & 183 \\
\hline $\begin{array}{l}\text { Number of } \\
\text { instruments }\end{array}$ & 21 & 21 & 21 & 12 & 12 & 12 \\
\hline $\begin{array}{l}\text { Arellano-Bond } \\
\text { test AR (1) }\end{array}$ & 0.005 & 0.007 & 0.003 & 0.056 & 0.018 & 0.078 \\
\hline $\begin{array}{l}\text { Arellano-Bond } \\
\text { test AR (2) }\end{array}$ & 0.518 & 0.998 & 0.074 & 0.717 & 0.283 & 0.647 \\
\hline $\begin{array}{l}\text { Hansen test } \\
\text { ( } p \text {-value) }\end{array}$ & 0.320 & 0.232 & 0.312 & 0.206 & 0.238 & 0.263 \\
\hline
\end{tabular}

(Note) (i) The columns display the results of System GMM regressions for corporate tax rate (1 to 3) and total tax rate (4 to 6) as dependent variables.

(ii) Regressions (1) and (4) are basic estimations and show the impact of each tax rate for all integration initiatives taken together (with exception of the EurAsEC). Regressions (2) and (5) show the results for the EU only and regressions (3) and (6) display the results for the CU only.

(iii) Robust standard errors are reported in parentheses. Stars indicate levels of significance: ***: 1 percent, **: 5 percent, *: 10 percent. 


\section{Spatial autoregressive model}

\section{Estimation}

As an enhancement of the above analysis, it is helpful to examine the spatial interaction between the countries' tax rates. The presence of spatial interaction within an integration area could meaningfully reinforce the assumption about the presence of tax competition in the region. Therefore, to determine whether the tax rates of the examined countries are spatially correlated, this study estimates a spatial lag model, also known as SAR. However, the spatial estimation is impaired by the small number of countries participating in CU and the EU. This is especially the case with regard to the total tax rate estimation, wherein the data availability only allows the inclusion of the 2007 eastward enlargement of the EU. Consequently, the results of the spatial estimation are relatively less reliable than those from the specifications based on the system GMM and the fixed-effects estimations.

As mentioned in Section II, Redoano (2014) and Davies and Voget (2008) already addressed the issue of spatial interaction within the EU with regard to corporate taxation. Therefore, this study confines the following estimation to only the sample of transition countries and investigates whether there are spatial spillovers between these countries after their EU entry.

Following the literature on such models by Cliff and Ord (1973), Anselin (1988), Elhorst (2003), and Lesage and Pace (2009), the following equation is suggested:

$$
y_{i t}=\gamma y_{i, t-1}+\rho W y_{i t}+\beta_{1} E U / C U_{i t}+\beta_{2} X_{i t}+\mu_{i}+\tau_{t}+\varepsilon_{i t}
$$

where

$y_{i t}$ represents the dependent corporate taxation variable (corporate tax rate or total tax rate).

$y_{i, t-1}$ on the right side of the equation represents the lagged dependent variable (similar to the GMM model). Including this in the model accounts for the autocorrelation of the corporate tax variables.

$\rho W y_{i t}$ is the spatial lag variable describing the actual spatial interaction outcome. $W$ is the spatial-weighting matrix based on the inverse distance between country capitals. The parameter $\rho$ basically describes the strength of the spatial relationship.

Similar to the fixed-effects equation, the $E U / C U$ variable indicates whether a country 
belongs to the EU or CU integration initiative.

$X$ represents the set of control variables, $\mu_{i}$ is the country fixed-effects, $\tau_{t}$ is the period fixed-effects, and $\varepsilon_{i t}$ is the error term.

To obtain optimal results, the dataset is modified as follows: (1) countries with missing tax values or control variables are removed ${ }^{17}$ and (2) the time span for the corporate tax rate is confined to the 2002 2012 period. These changes enable me to produce a fully balanced dataset of countries, which is advantageous in receiving reliable results using the above equation.

It is well known that because of the endogeneity of the spatial lag variable, the standard ordinary least squares (OLS) estimator produces biased results (Anselin 1988). Therefore, many other estimation strategies have been applied to the spatial models, of which the most prevalent are the maximum likelihood (ML) estimation (Ord 1975, Lee 2004, Lee and Yu 2010) and the GMM and GS2SLS (generalized spatial two-stage leastsquares) estimations (Kelejian and Prucha 1999, 2010; Arraiz et al. 2010).

For the purposes of this study, a standard ML estimation, as suggested by Lee (2004), is sufficient. By comparison, according to LeSage and Pace (2009), the ML estimation is fairly easy to compute and has a low risk of specification errors in the model.

\footnotetext{
${ }^{17}$ The countries removed from the corporate tax rate dataset are as follows: Kosovo, Turkmenistan, Tajikistan, Kyrgyzstan, Moldova, Azerbaijan, and Uzbekistan. The countries removed from the total tax rate dataset are Kosovo and Turkmenistan.
} 


\section{Results}

Table 4. Spatial interaction between corporate taxation levels

\begin{tabular}{|c|c|c|c|c|}
\hline \multirow{3}{*}{ Model } & \multicolumn{4}{|c|}{ Spatial Autocorrelation Model } \\
\hline & \multicolumn{2}{|c|}{$\begin{array}{l}\text { Corporate Tax Rate } \\
\text { (since 2002) }\end{array}$} & \multicolumn{2}{|c|}{$\begin{array}{l}\text { Total Tax Rate } \\
\text { (since 2005) }\end{array}$} \\
\hline & (1) & (2) & (3) & (4) \\
\hline$E U$ & $\begin{array}{l}-0.25 \\
(0.563)\end{array}$ & & $\begin{array}{l}3.679 \\
(2.381)\end{array}$ & \\
\hline$C U$ & & $\begin{array}{c}-1.335^{* * *} * \\
(0.328)\end{array}$ & & $\begin{array}{c}-6.779 * \\
(3.561)\end{array}$ \\
\hline Lagged dependent variable & $\begin{array}{c}0.667 * * * \\
(0.048)\end{array}$ & $\begin{array}{c}0.659 * * * \\
(0.048)\end{array}$ & $\begin{array}{c}0.863^{* * *} \\
(0.105)\end{array}$ & $\begin{array}{r}0.704 * * * \\
(0.085)\end{array}$ \\
\hline Spatial Lag Wy & $\begin{array}{l}-0.203 \\
(0.127)\end{array}$ & $\begin{array}{l}-0.162 \\
(0.121)\end{array}$ & $\begin{array}{c}-0.647 * * * \\
(0.140)\end{array}$ & $\begin{array}{l}0.081 \\
(0.126)\end{array}$ \\
\hline Government expenditure & $\begin{array}{l}0.108 \\
(0.07)\end{array}$ & $\begin{array}{c}0.086 \\
(0.070)\end{array}$ & $\begin{array}{l}0.40^{* *} \\
(0.193)\end{array}$ & $\begin{array}{c}0.378 * * \\
(0.171)\end{array}$ \\
\hline Trade & $\begin{array}{l}-0.009 \\
(0.014)\end{array}$ & $\begin{array}{l}-0.013 \\
(0.013)\end{array}$ & $\begin{array}{c}0.026 \\
(0.038)\end{array}$ & $\begin{array}{l}0.009 \\
(0.042)\end{array}$ \\
\hline GDP/Capita & $\begin{array}{c}0.0004 \\
(0.0003)\end{array}$ & $\begin{array}{c}0.0004 \\
(0.0003)\end{array}$ & $\begin{array}{l}-0.0004 \\
(0.0009)\end{array}$ & $\begin{array}{l}-0.0004 \\
(0.0009)\end{array}$ \\
\hline Dependency ratio & $\begin{array}{c}0.079 \\
(0.120)\end{array}$ & $\begin{array}{c}0.065 \\
(0.123)\end{array}$ & $\begin{array}{c}0.086 \\
(0.171)\end{array}$ & $\begin{array}{c}0.254 \\
(0.192)\end{array}$ \\
\hline$G D P$ & $\begin{array}{c}0.002 \\
(0.004) \\
\end{array}$ & $\begin{array}{c}0.005 \\
(0.003) \\
\end{array}$ & $\begin{array}{c}0.042 * * \\
(0.017)\end{array}$ & $\begin{array}{c}0.072 * * \\
(0.025)\end{array}$ \\
\hline Number of countries & 22 & 22 & 27 & 27 \\
\hline Number of observations & 220 & 220 & 189 & 189 \\
\hline Log-Likehood & -411.84 & -410.38 & -536.46 & -513.73 \\
\hline$R^{2}$ (within) & 0.71 & 0.71 & 0.72 & 0.75 \\
\hline
\end{tabular}

(Note) (i) The columns show results of spatial regression for corporate tax rate (1 to 2$)$ and total tax rate (3 to 4$)$. The columns (1) and (3) show the results for the EU and columns (2) and (4) for the CU.

(ii) Variable of interest is the Spatial Lag $W y$, which describes the strength of spatial relationship.

(iii) Robust standard errors are reported in parentheses. Stars indicate levels of significance: ***: 1 percent, **: 5 percent, *: 10 percent.

With regard to the EU variable and the lagged dependent variables, the results are similar to those of the GMM estimations. The lagged dependent variables remain strongly significant in all specifications. The EU variable is not significant but remains negative for the statutory corporate tax rate estimation and positive for the total tax rate estimation. The reason for the positive correlation is probably the same as in the case of 
the GMM estimation: the data do not include the 2004 EU enlargement.

The spatial lag variable, in contrast, is not significant in the corporate tax rate specifications (1) and (2). It is strongly significant only in specification (3) with the total tax rate and EU.

Overall, the results do not show any relevant spatial spillover effects, except for specification (3). However, because of the above issues with sample size, these specifications are much less reliable than the GMM and fixed-effects estimations and therefore do not provide strong enough evidence for no spatial spillover effects.

\section{Conclusions}

The results from the basic estimations confirm that there is a link between corporate taxation levels and regional integration. In practice, this suggests that the negative trend in corporate taxation can, to a large extent, be attributed to the progressing regional integration initiatives.

The GMM and spatial lag estimations also confirm that the corporate tax rates strongly depend on their previous values. The spatial spillovers between the EU countries seem to be real, at least partially.

The results show that the accession to both the EU and EEU triggered an adjustment trend, which has driven the corporate tax levels downwards. In the case of the EEU, this adjustment seems to be driven by Russia's corporate tax levels. To stay competitive, countries have lowered their tax rates by adjusting them to Russia's relatively low tax rates.

A similar trend is also visible in the Doing Business rankings, where Kazakhstan and Belarus improved their positions against Russia. Russia's ranking remained quite stable over this period. The most probable reason for this development is the sheer size of Russia's economy compared with Kazakhstan and Belarus, and this factor supports the aforementioned agglomeration hypothesis. Apparently, the Russian government did not see a need to adjust its corporate tax rates or its business climate in general, despite the danger of potential outflow of corporations. This response may, however, change given the current developments in the energy markets. All the major EEU countries are, to a large extent, dependent on revenues from oil and gas to support their state budgets- 
Kazakhstan and Russia directly and Belarus indirectly since its export revenues are dependent on refining Russian oil. ${ }^{18}$ In light of the recent fluctuations in oil prices, it is therefore likely that lower (and/or unstable) revenues from the oil industry to the state budgets will be a sensitive issue in terms of corporate taxation revenues, especially in Russia.

Additionally, this stance will be reinforced by further tax competition. It is very likely that the Eurasian integration process will, in the long term, face problems similar to those in the EU in terms of tax competition. As already mentioned, businesses have learned to exploit the differences among the national tax systems of the EU Member States. As a consequence, the European Commission issued a Code of Conduct as early as 1997, in which such tax competition was explicitly named as a harmful element due to the various actions by nation states who attempted to attract potential investments. This debate was given renewed momentum in 2016 with the issuance of the Anti-Tax Avoidance Package by the EU Commission. The package, which includes a legally binding directive, is especially aimed at creating a fairer tax system for all Member States and preventing aggressive tax planning, which has been the main reason for tax base erosion and the race to the bottom in terms of corporate taxation.

Considering the above-mentioned arguments as a whole, it is likely that the EEU institutions will try to implement similar tax avoidance measures as the EU in the future. The tendencies in such directions are already present with the example of relatively recent changes in civil legislation in Kazakhstan and Russia that aim to constrain the power of offshore investors. The so-called "deoffshorization" has been introduced to strengthen fiscal budget revenues through, among other options, the introduction of taxes on Russian companies registered in foreign tax havens, depriving such firms from state guarantees, and banning foreign companies from competition for state contracts. Similar measures have also been introduced in Kazakhstan. ${ }^{19}$

This study also shows that tax competition can be present in countries with both democratic and autocratic government structures. Countries feel the pressure to engage in tax competition after joining an integration initiative, regardless of whether they have democratic or autocratic government structures.

\footnotetext{
${ }^{18}$ For the various dependence on direct/indirect energy revenues, see Movchan (2015), Smok (2016) and The Jamestown Foundation (2015).

${ }^{19}$ For Kazakhstan, see the overview in Bregonje and Bezborodov (2010). For Russia, see the The Moscow Times from Dec. 20 2013: Putin's 'Deoffshorization' Brings Major Firms Back to Taxman. Newest changes in the legislation promoting "deoffshorization" in Russia have been introduced by the Federal Law in 2014: Federal Law Amendment. "Deoffshorisation Law": On Amendments to Parts One and Two of the Tax Code of the Russian Federation.
} 
The study also indicates that Eurasian integration is effectively taking place. Some critics assert that the integration initiatives in the post-Soviet sphere are not actually being implemented (Libman 2007, Valovaya 2012). However, the presence of the linkage between corporate taxation and integration within the EurAsEC and CU/EEU confirms that these integration initiatives are not only being implemented but also work effectively in practice.

One of the unresolved issues is the question of an adequate measure of corporate taxation for the transition countries. The lack of sufficient and reliable data reflecting the tax base developments in all the transition countries remains problematic, and access to this data would contribute immensely toward calculating the real tax burden for companies. Further research is also required regarding the effective and marginal corporate tax rates in those countries. Establishing a database containing this information would yield clearer results for any further analysis of the relation between taxes and regional integration.

The Eurasian integration process is still relatively new, and its long-term effects are untested. Thus, a broader assessment of the implications of the integration of these fiscal policies will only be possible after the passage of time.

Received 6 October 2016, Revised 10 January 2017, Accepted 25 January 2017

\section{References}

Abbas, Ali S. M., Klemm, Alexander, Bedi, Sukhmani, and Junhyung Park. "A partial race to the bottom: corporate tax developments in emerging and developing economies." International Tax and Public Finance 20 (2013): 596-617.

Anselin, Luc. Spatial Econometrics: Methods and Models, Dordrecht: Kluwer Academic Publishers, 1988.

Arraiz, Irani, Drukker, David M., Kelejian, Harry H., and Ingmar R. Prucha. "A spatial Cliff-ord-type model with heteroskedastic innovations: small and large sample results." Journal of Regional Science 50 (2010): 592-614.

Arellano, Manuel, and Stephen Bond. "Some tests of specification for panel data: Monte 
Carlo evidence and an application to employment equations." Review of Economic Studies 58 (1991): 277-297.

Arellano, Manuel, and Olympia Bover. "Another look at the instrumental variables estimation of error-components models.” Journal of Econometrics 68 (1995): 29-51.

Baldwin, Richard E., and Paul Krugman. "Agglomeration, integration and tax harmonisation." European Economic Review 48 (2004): 1-23.

Blundell, Richard, and Stephen Bond. "Initial conditions and moment restrictions in dynamic panel data models." Journal of Econometrics 87 (1998): 115-143.

Bregonje, Richard, and Sergey Bezborodov. "The Battle against Tax Havens Rages on in Kazakhstan...Tax Treaty Partners Being Victimized.” Intertax 38 (2010): 118-127.

Cliff, Andrew D., and Keith J. Ord. Spatial Autocorrelation. London: Pion Ltd., 1973.

Davies, Ronald B., and Johannes Voget. J. "Tax Competition in an Expanding European Union." Oxford University Centre for Business Taxation Working Paper Series WP 08/30 (2008): 1-38.

Devereux, Michael P., and Rachel Griffith. "Evaluating tax policy for location decisions." International Tax and Public Finance 10 (2003): 107-126.

Devereux, Michael P., Griffith, Rachel, Klemm, Alexander, Thum, Marcel, and Marco Ottaviani. "Corporate income tax reforms and international tax competition." Economic Policy 17 (2002): 449-495.

Devereux Michael P., Lockwood, Ben, and Michela Redoano. "Do countries compete over corporate tax rates?” Journal of Public Economics 92 (2008): 1210-1235.

Baker \& McKenzie. Doing Business in Uzbekistan (2009 \& 2010). Accessed January 02, 2015. http://www.bakermckenzie.com/en/.

Dreher, Axel. "The influence of globalization on taxes and social policy: An empirical analysis for OECD countries.” European Journal of Political Economy 22 (2006): 179201.

Elhorst, Paul J. "Specification and Estimation of Spatial Panel Data Models.” International Regional Science Review 26 (2003): 244-268.

EU Commission. "Harmful tax competition.” (1997). Accessed January 5, 2017. 
http://ec.europa.eu/taxation_customs/business/company-tax/harmful-tax-competition en.

EU Commission. “Anti-Tax Avoidance Package.” (2016) Accessed January 5, 2017. http://ec.europa.eu/taxation_customs/business/company-tax/anti-tax-avoidancepackage en.

EU Council Directive L193/1 of July 12, 2016. Accessed January 7, 2016.

http://eur-lex.europa.eu/legal-content/EN/TXT/?uri=uriserv:OJ.L_.2016.193.01.0001.01. ENG\&toc $=$ OJ:L:2016:193:TOC.

Eurasian Economic Commission. "Eurasian Economic Integration: Facts and Figures.”(2013) Accessed May 30, 2015. http://www.eurasiancommission.org/.

Federal Law Amendment (Russian Federation). "Deoffshorisation Law": On Amendments to Parts One and Two of the Tax Code of the Russian Federation." (2014) Accessed June 4, 2015. http://publication.pravo.gov.ru/Document/View/0001201411 250003.

Garrett, Geoffrey. "Capital mobility, trade, and the domestic politics of economic policy." International Organization 49 (1995): 657-697.

Genschel, Philipp, Kemmerling, Achim, and Eric Seils. "Accelerating Downhill: How the EU Shapes Corporate Tax Competition in the Single Market." Journal of Common Market Studies 49 (2011): 585-606.

Hansen, Lars P. "Large sample properties of generalized method of moments estimators." Econometrica 50 (1982): 1029-1054.

Hansson, Assa, and Karin Olofsdotter. "Integration and tax competition: an empirical study of OECD countries.” Lund University Working Paper 2005/4 (2005): 1-45.

International Monetary Fonds (IMF). World Economic Outlook Database. Accessed March 12, 2015. https://www.imf.org/external/data.htm.

Invest in Georgia. Georgian National Investment Agency. Accessed March 12, 2015. http://www.investingeorgia.org/?84/tax_system/.

The Jamestown Foundation. "Kazakhstan Joins the List of Suffering Oil Exporters," OilPrice.com (September 22, 2015), OilPrice.com, accessed January 2, 2017. http:// oilprice.com/Latest-Energy-News/World-News/Kazakhstan-Joins-The-List-OfSuffering-Oil-Exporters.html. 
Keen, Michael, and Alejandro Simone. "Is tax competition harming developing countries more than developed?" Tax Notes International (Special Supplement) 34 (2004): 13171325.

Kelejian, Harry H., and Ingmar R. Prucha. "A generalized moments estimator for the autoregressive parameter in a spatial model." International Economic Review 40 (1999): 509-533.

Kelejian, Harry H., and Ingmar R. Prucha. "Specification and estimation of spatial autoregressive models with autoregressive and heteroskedastic disturbances." Journal of Econometrics, vol. 157 (2010): 53-67.

Klemm, Alexander and Stefan van Parys. "Empirical evidence on the effects of tax incentives.” International Tax and Public Finance 19 (2012): 393-423.

KPMG. "Corporate and Indirect Tax Survey 2011."Accessed November 10, 2015. Kpmg.com.

KPMG. Corporate Tax Rate Table. Accessed November 10, 2015. https://home.kpmg. com/xx/en/home/services/tax/tax-tools-and-resources/tax-rates-online/corporate-taxrates-table.html.

Krogstrup, Simone S. (2006), "Are corporate taxes racing to the bottom in the European Union?" Unpublished Manuscript.

Accessed January 2, 2017. http://www.tcd.ie/Economics/staff/minnsc/DEW/Krogstrup.pdf.

Lee. Lung-Fei. "Asymptotic Distributions of Quasi-Maximum Likelihood Estimators for Spatial Autoregressive Models.” Econometrica 72 (2004): 1899-1925.

Lee, Lung-Fei, and Jihai Yu. "Estimation of spatial autoregressive panel data models with fixed effects." Journal of Econometrics 154 (2010): 165-185.

LeSage, James, and Robert K. Pace. Introduction to Spatial Econometrics. London: Taylor \& Francis Group, 2009.

Libman, Alexander. "Regionalization and Regionalism in the Post-Soviet Space: Current Status and Implications for Institutional Development.” Europe-Asia Studies 59 (2007): 401-430.

Libman, Alexander, and Evgeny Vinokurov. "Regional integration and economic convergence in the post-Soviet space: experience of the decade of growth." Journal of 
Common Market Studies 50 (2012): 112-128.

Mendoza, Enrique G., Razin, Assaf, and Linda L. Tesar. "Effective tax rates in macroeconomics: cross-country estimates of tax rates on factor incomes and consumption." Journal of Monetary Economics 34 (1994): 297-323.

Mendoza, Enrique G and Linda L. Tesar. "Why hasn't tax competition triggered a race to the bottom? Some quantitative lessons from the EU." Journal of Monetary Economics 52 (2005): 163-204.

Ministry of Taxes Republic of Azerbajian. Tax Code of the Republic of Azerbaijan 2000. Accessed January 10, 2015. http://www.taxes.gov.az/eng/qanun/f9.html.

The Moscow Times. "Putin's 'Deoffshorization' Brings Major Firms Back to Taxman." December 20, 2013. Accessed December 24, 2016.

https://themoscowtimes.com/articles/putins-deoffshorization-brings-major-firms-backto-taxman-30664.

Movchan, Andrey, "Just an Oil Company? The True Extent of Russia's Dependency on Oil and Gas," Carnegie Moscow Center, September 14, 2015. Accessed December 20, 2016. http://carnegie.ru/commentary/?fa=61272.

Nickell, Stephen. "Biases in dynamic models with fixed effects." Econometrica 49 (1981): 1417-1426.

OECD. "Fundamental reform of corporate income tax." OECD Tax Policy Studies 16 (2007), doi: 10.1787/9789264038127-en.

Ord, Keith. "Estimation Methods for Models of Spatial Interaction." Journal of the American Statistical Association 70 (1975): 120-126.

Quinn, Dennis. "The correlates of change in international financial regulations." American Political Science Review 91 (1997): 531-551.

Redoano, Michela. "Tax competition among European countries. Does the EU matter?" European Journal of Political Economy 34 (2014): 353-371.

Rodrik, Dani. Has Globalization Gone Too Far? Washington, DC: Institute for International Economics, 1997.

Roodman, David. "“'Practitioners" corner: a note on the theme of too many instruments." 
Oxford Bulletin of Economics and Statistics 71 (2009): 135-158.

Sachs, Jeffrey.D., and Andrew Warner. "Economic reform and the process of global integration." Brookings Papers on Economic Activity 1 (1995): 1-118.

Semibratova, Irina, "Russian business went to Kazakhstan," Zakon.kz, accessed January 5, 2017. http://www.zakon.kz/212982-rossijjskijj-biznes-napravilsja-v.html. (In Russian language).

Slemrod, Joel. "Are corporate tax rates, or countries, converging?" Journal of Public Economics 88 (2004): 1169-1186.

Smok, Vadzim, "Belarus Struggles to Reduce Energy Dependence on Russia," Belarus Digest, February 01, 2016. Accessed January 2 2017. http://belarusdigest.com/story/ belarus-struggles-reduce-energy-dependence-russia-24413.

Soto, Marcelo. "System GMM Estimation with a small sample." Working Paper 395. Barcelona Economics Working Paper Series (2009): 1-28.

Stepanyan, Vahram. "Reforming Tax Systems: Experience of the Baltics, Russia, and Other Countries of the Former Soviet Union." IMF Working Paper WP/03/173 (2003): $1-30$.

Swank, Duane. "Mobile capital, democratic institutions, and the public economy in advanced industrial societies." Journal of Comparative Policy Analysis 3 (2001): 133162.

Uzoinvest. National Investment Promotion Agency (Uzbekistan). Accessed 12 March, 2015. http://www.uzinfoinvest.uz/eng/investment_guide/tax_and_accounting_systems/.

Valovaya, Tatyana. "Eurasian Economic Integration: Origins, Patterns, and Outlooks.” In Eurasian Integration Yearbook 2012. Annual publication of the Eurasian Development Bank, edited by Evgeny Vinokurov, 42-61. Almaty: Eurasian Development Bank, 2012.

World Bank. "Ease of Doing Business Reports." Accessed August 30, 2016. http://www. doingbusiness.org/reports/global-reports/doing-business-2016.

World Bank. World Development Indicators. World Bank Databank. Accessed January 10, 2015. http://databank.worldbank.org/data/home.aspx.

Zodrow, George, and Peter Mieszkowski. "Pigou, Tiebout, property taxation, and the underprovision of local public goods." Journal of Urban Economics 19 (1986): 356-370. 


\section{Appendix 1: Countries and integration initiatives included in the dataset}

\begin{tabular}{|c|c|c|c|c|c|c|c|c|}
\hline \multicolumn{9}{|c|}{ Countries and periods } \\
\hline \multirow{2}{*}{ Europe } & \multirow{2}{*}{ Periods } & \multicolumn{3}{|c|}{ Accession year } & \multirow{2}{*}{ Asia } & \multirow{2}{*}{ Periods } & \multicolumn{2}{|c|}{ Accession year } \\
\hline & & $\mathbf{E U}$ & EurAsEC & $\mathbf{C U}$ & & & EurAsEC & $\mathbf{C U}$ \\
\hline Albania & 2000 2012 & & & & Armenia & 2000 2012 & & \\
\hline Bulgaria & $2000 \sim 2012$ & 2007 & & & Azerbaijan & $2000 \sim 2012$ & & \\
\hline $\begin{array}{l}\text { Bosnia and } \\
\text { Hercegovina }\end{array}$ & $2000 \sim 2012$ & & & & Georgia & $2000 \sim 2012$ & & \\
\hline Belarus & 2000 2012 & & 2001 & 2010 & Kazakhstan & 2000 2012 & 2001 & 2010 \\
\hline $\begin{array}{l}\text { Czech } \\
\text { Republic }\end{array}$ & 2000 2012 & 2004 & & & Kirgizstan & 2000 2012 & 2001 & \\
\hline Estonia & 2000 2012 & 2004 & & & Tajikistan & 2000 2012 & 2001 & \\
\hline Croatia & $2000 \sim 2012$ & & & & Turkmenistan & 2000 2012 & & \\
\hline Hungary & 2000 2012 & 2004 & & & Uzbekistan & 2000 2012 & $2006 \sim 2008$ & \\
\hline Kosovo & $2000 \sim 2012$ & & & & & & & \\
\hline Lithuania & 2000 2012 & 2004 & & & & & & \\
\hline Latvia & $2000 \sim 2012$ & 2004 & & & & & & \\
\hline Moldova & $2000 \sim 2012$ & & & & & & & \\
\hline Macedonia & 2000 2012 & & & & & & & \\
\hline Montenegro & 2000 2012 & & & & & & & \\
\hline Poland & 2000 2012 & 2004 & & & & & & \\
\hline Romania & 2000 2012 & 2007 & & & & & & \\
\hline Russia & 2000 2012 & & 2001 & 2010 & & & & \\
\hline Serbia & 2000 2012 & & & & & & & \\
\hline Slovakia & 2000 2012 & 2004 & & & & & & \\
\hline Slovenia & 2000 2012 & 2004 & & & & & & \\
\hline Ukraine & 2000 2012 & & & & & & & \\
\hline
\end{tabular}




\section{Appendix 2: Descriptive statistics}

\begin{tabular}{|l|c|c|c|c|c|}
\hline \multicolumn{1}{|c|}{ Variable } & Mean & $\begin{array}{c}\text { Standard } \\
\text { deviation }\end{array}$ & Minimum & Maximum & Observations \\
\hline Corporate tax rate & 19.5621 & 6.23835 & 9 & 35 & 282 \\
\hline Total tax rate & 47.8058 & 21.1258 & 9.7 & 137.5 & 219 \\
\hline Government expenditure & 35.5086 & 9.48611 & 8.46 & 59.599 & 366 \\
\hline Trade & 103.5558 & 30.8437 & 46.11 & 199.68 & 365 \\
\hline GDP per capita & 5131.895 & 4447.417 & 234.3 & 20682.9 & 377 \\
\hline Dependency ratio & 48.0178 & 8.12805 & 37 & 85 & 365 \\
\hline LOG_GDP & 68.76176 & 154.0067 & 1.449651 & 980.583 & 377 \\
\hline
\end{tabular}

